\title{
The Bene-Ideal: China's Cosmopolitan Vision of World Order
}

\author{
Mingjun Lu'
}

Received: 11 March 2016/Accepted: 11 March 2016/Published online: 5 April 2016

(C) Fudan University and Springer Science+Business Media Singapore 2016

\begin{abstract}
With the rise of China in modern global affairs, the construction of a Chinese international relations (IR) theory that accounts for both its distinctive vision of world order and its overall foreign policy position has become a topical issue. This essay proposes a cosmopolitan approach to Chinese IR centered on the concept of bene-ideal, by which I mean the cosmopolitan wish to embrace diversity and benefit others with one's abundance. The bene-ideal framework will contribute at once to Chinese IR construction, foreign policy making, and national identity building.
\end{abstract}

Keywords Bene-ideal - World order · Cosmopolitanism - The Chinese dream • Civilizational identity $\cdot$ Civilizational cosmopolis

\section{Introduction}

Less than a decade ago, amazed by China's miraculous economic takeoff, scholars were hotly disputing what China wants and what are its intentions for the international system. ${ }^{1}$ The terms of debate have changed after the global financial crisis in 2008 and China overtook Japan as the world's second largest economy in 2010. Recognizing China's leadership potential in global governance, current debates start to emphasize what China can contribute to the international society. ${ }^{2}$ Instead of a revisionist that seeks to unsettle the international system from which it

\footnotetext{
${ }^{1}$ On debates before 2008 see Johnston (2003), Zheng (2003), Legro (2007) and Callahan (2008). Unless specially noted, the English translations of Chinese works are my own.

2 On debates after 2008 see Barabantseva (2009), Buzan (2010a) and Zhang Xiaoming (2010).
}

Mingjun Lu

mingjun.lu@mail.utoronto.ca

1 1404-35 Charles St. West, Toronto, ON M4Y 1R6, Canada 
has apparently benefited, China tends to view itself as a proactive reformer committed to addressing problems intrinsic to the existing system. ${ }^{3}$ Native scholars seem to have reached a consensus that China would make a significant contribution to global knowledge reproduction by constructing a Chinese IR theory that accords with its new global status. ${ }^{4}$

This essay participates in this emerging trend to formulate a Chinese IR theory by proposing a cosmopolitan approach based on what I would call a bene-ideal [惠及天 下], by which I mean the cosmopolitan wish to embrace diversity and benefit others with one's abundance. ${ }^{5}$ As a long-cherished ethical and spiritual value, the bene-ideal integrates both the Taoist and Confucian insights on cosmopolitanism-the Confucian maxim “diversity without uniformity” [和而不同] (Analects 13.23), Mencius' injunction to "cultivate the self when utterly deprived, and provide for the world when fully endowed” [穷则独善其身, 达则兼济天下] (Mencius 13.9), as well as the Taoist notion of the equality of all forms of life. [万物与我齐一] (zhuangzi Chap2) The liberal generosity to engage with diversity and benefit others with one's abundance expressed in these core Confucian and Taoist concepts bespeaks none other than an altruistic cosmopolitanism. An IR framework centered on the concept of the bene-ideal, I argue, indicates a cosmopolitan vision of the world as a civilizational cosmopolis that features peaceful and mutually enabling interactions among all civilizations. What distinguishes such a civilizational community is its commitment to achieving mutual benefits or win-win outcomes through cosmopolitan good will and generosity to share the fruits of one's development.

By cosmopolitanism, I mean its normative-philosophical sense that entails the hypothesis of a shared human identity and the valuation of differences. Cosmopolitan thinking is a prominent feature of an increasingly globalized world that brings into contact many previously unrelated and isolated cultures, a development that renders it imperative to reconsider the global system by taking into account these new forms of transnational communications. Moreover, as many formerly peripheral cultures start to achieve autonomy and the Western civilization gradually loses its legitimacy to represent all civilizations, a paradigmatic shift in IR studies assumes topical urgency. According to Robert Went, "the defects of contemporary globalization are bringing cosmopolitical ideas once again to the forefront. And this revival is increasingly linked to proposals for new forms of participatory democracy". ${ }^{6}$ Roland Robertson holds that since "diversity is in and of itself good both for the system and for units within the system", "pluralism must be a constitutive feature of the global system, and has to be legitimized as such". 7 So

\footnotetext{
${ }^{3}$ For China's revisionism also see Johnston (2003: 56). For China as a status quo power see Pan (2008); and Feng (2008).

4 The Chinese IR consists of two key strands. Yan Xuetong and colleagues emphasize the relevance of Chinese history to IR (see Yan 2011). By contrast, Qin $(2009,2011)$ advocates constructing a distinctive Chinese IR. For the consensus see Wang and Buzan (2014: 8, 13); and Cunningham-Cross and Callahan (2011).

5 The quotes of Chinese classics are taken from the modern annotated editions: The Analects (2012); Mencius (2014); Xunzi (2013); The mean and great learning (2006); Zhuangzi (2015); Laozi (2013) and Zuozhuan (2013).

6 Went (2004: 348).

7 Robertson (1992: 70, 75).
} 
attitudes towards cultural diversities are pivotal to a cosmopolitan conception of new global norms and principles. David Hollinger defines a cosmopolitan spirit as both a "universal will to find common ground" and a "cosmopolitan will to engage human diversity". 8 The bene-ideal model that prizes mutually beneficial interactions among different civilizations points precisely to such a universal perspective and liberal cosmopolitanism to find commonality and embrace pluralism. For David Held, cosmopolitanism connotes "the ethical and political space which sets out the terms of reference for the recognition of people's equal moral worth, their active agency and what is required for their autonomy and development". "Active agency" and "equal moral worth" are two primary goals of a civilizational cosmopolis that seeks to secure the "ethical and political space" for those only marginally represented in the existing international system.

The cosmopolitan framework anchored in the bene-ideal marks out a new conceptual parameter for the Chinese IR, on three accounts. First, as Qin Yaqing points out, the identification of a core concept that corresponds to the "hegemonic liberal order" in the American IR and the "international society" in the English school is central to formulating a Chinese IR. ${ }^{10}$ The bene-ideal that signifies a cosmopolitan conception of world order gestures towards such a core concept. Second, according to Wang Jiangli and Barry Buzan, all general IR theories "identify some basic mechanism or driving force that explains how and why things work the way they do". For instance, realism views power politics, liberalism rational choice, and Marxism class struggle as the key driver of the international system. While post-structuralism focuses on discursive processes, the English school is committed to supra-national order and justice. ${ }^{11}$ By contrast, the beneideal envisions a community of civilizations sustained by interactive and mutually reinforcing dialogues. Third, Buzan maintains that a systematic IR theory should clearly signal a nation's "coherent and specific image of itself and how it wants to relate to the rest of international society in the longer term". ${ }^{12}$ The bene-ideal means to articulate China's foreign policy position vis a vis both itself and the rest of the world. Put differently, the bene-ideal signifies not only China's vision of world order but also its conception of national identity. "The Chinese dream" initiative that seeks to revitalize China's civilizational heritage, I propose, provides an optimal platform to reconstitute its national identity.

This essay consists of seven parts. Part I is a brief introduction of my thesis. Part II summarizes mainstream conceptions of international order and their Westerncentric perspective. Part III looks into how the cosmopolitan insights in Taoism and Confucianism provide philosophical justification for the bene-ideal. Part IV studies how the bene-ideal could serve as a pertinent framework to conceptualize Chinese foreign policy. Part V investigates how the Dream project can help reshape national

\footnotetext{
8 Hollinger (1995: 84).

9 Held (2010: 49).

10 Qin (2009).

11 Wang and Buzan (2014:13).

12 Buzan (2010a: 35).
} 
identity. Part VI examines the world order symbolized by the bene-ideal through the concept of civilizational cosmopolis. Part VII sums up my argument.

\section{Western Visions of the International Order}

This essay adopts the concept of world or international order as defined by Hedley Bull, champion of the English School that is noted for its achievements in IR studies. Bull proposes the concept of "international society" and defines it as "a society of states", which, impelled by "common interests or values", agree to "be bound together by a common set of rules" and cooperate "in the working of common institutions". Accordingly, international order represents "a pattern of activity that sustains the elementary or primary goals" of such a society of states. Bull distinguishes international from world order: whereas the former addresses the "order among states", the latter refers to the "order in the great society of all mankind". ${ }^{13}$ The postwar order that promotes the neoliberal market economy and such liberal values as democracy and human rights is an international order that involve relations among states. This West-centered order, however, does not represent the world order that also governs non-Western states. The bene-ideal proposed in this essay reflects more the "order in the great society of all mankind" than the "order among states".

The global financial crisis, the increasing number of failing democracies, and the emergence of growing economies have combined to call into question the legitimacy of the international order shaped by the Western normative framework. This challenge has given rise to a host of competing visions of world order. John G. Ruggie argues that the "international authority" of the neoliberal economic order is justified because it is "a concrete manifestation of the internationalization of political authority" that "represents a fusion of power with legitimate social purpose". ${ }^{14}$ For G. John Ikenberry, though challenged by the global realignment of powers after the cold war, the liberal international order led by the US could be reinvented as a "liberal leviathan". 15

The IR study has seen a "cultural turn" in the past three decades, a turn that is exemplified in the doctrines propounded by Samuel Huntington and the English school. ${ }^{16}$ Bull locates the integrative force of the international society in "a common culture", by which he means both "a common intellectual tradition and stock of ideas that facilitated communication" and the "common values" that could moderate conflicts of interests. ${ }^{17}$ But as Buzan notes, "culture can be either supportive or destructive of international society", because a society of states bonded by a shared culture could become unstable when it starts to expand beyond its original base. Instead, Buzan argues, the international order is largely shaped by interactions

\footnotetext{
13 Bull (1977; Reprint 2002: 8, 13, 49,19).

14 Ruggie (1982: 382).

15 Ikenberry (2011).

16 Jackson (2008).

17 Bull (1977; Reprint 2002: 15, 110).
} 
between international norms and domestic politics. These transnational communications, Buzan says, could be summed up by two accounts-the Vanguardist and the Syncretist. The Vanguardist account "emphasizes the centrality of Europe in the expansion story and projects a rather one-way view of cultural transmission from the West to the rest of the world". By contrast, the Syncretist account "puts more emphasis on the interplay of civilizations during the expansion process, and takes a more fluid and interactive view of cultural transmission generally". ${ }^{18}$ Whereas the English School regards cultural unity and interaction as a bonding force of world order, Huntington focuses his attention on conflicts generated by encounters among different civilizations. For Huntington, among the 21 major civilizations in human history, only six still exist, that is, the Western, Confucian, Islamic, Hindu, SlavicOrthodox, and Latin American, which, plus the African and Japanese civilizations, constitute the current global civilizational landscape. The "clashes" between these civilizations, he claims, would determine the general contour of international relations. $^{19}$

Whether economic, ideological, or cultural, a common feature marking the mainstream conception of international order is its Western-centric perspective. Even in the modern age that has witnessed the assertion or re-assertion of multiple cultural forms and standards, Western observers still tend to map an international order centered on the Western "Standard of civilization". Ruggie's neoliberal economic order is justified by the legitimacy of the political authority of the Western states. For Ikenberry, "American power and liberal order share a historical moment: they are tied together and rely on each other". ${ }^{20}$ The English school locates the cultural denominator of the international society in none other than the Western culture. Though the idea of the "interplay of civilizations" sounds more inclusive, both of Buzan's scenarios presuppose an expansion that starts from the Western culture.

The Western-centric approach is problematic when applied to the practical societal and political conditions of different cultures. Jan Melissen and Ingrid d'Hooghe argue that "no truly global debate should take place within either the realm, on the terms, or within the self-contained literature of a single civilization". ${ }^{21}$ Mel Van Elteren also holds that American culture "does not encompass all cultural varieties of humankind" and that "to uphold American-style democracy (as it exists today) as the world's exemplary of a true democracy is problematic", since "it is certainly not the panacea to all of other people's societal problems". ${ }^{22}$ For David Porter, we cannot negate such universalist claims that all people share some basic needs and legitimate aspirations, and "it is equally hard to deny that communities differ in their histories, institutions, and value systems, and that a particular set of norms that has evolved in one context (such as the European Enlightenment) might not be readily accepted or function well in another (such as modern China)". ${ }^{23}$ Even

\footnotetext{
18 Buzan (2010b: 2, 3).

19 Huntington (1993: 25).

20 Ikenberry (2006: 17).

21 Melissen and d'Hooghe (2014: 27).

22 Van Elteren (2006: 212).

23 Porter (2011: 7, 8).
} 
Ikenberry admits that the American unipolar order raises the "legitimacy problems for the lead state" against "other power configurations-such as bipolar or multipolar orders". ${ }^{24}$ In fact, it is precisely the inadequacy of the US-led order to address the distinct conditions in non-Western societies that renders it imperative to formulate an alternative set of international norms.

\section{The Bene-Ideal and the Confucian and Taoist Insights on Cosmopolitanism}

The bene-ideal that attends to the voice and rights of all civilizations in the global system provides such an alternative framework. Rather than a random concept, the bene-ideal is solidly rooted in Chinese historical and cultural resources, intellectual assets that have endured centuries of test. Daniel A. Bell also notes that "the Chinese state is viewed as the carrier of cosmopolitan values", but he argues that "the cosmopolitan ideal is radically inconsistent with key Confucian values". ${ }^{25}$ In truth, a defining feature of Confucianism is altruistic cosmopolitanism, and this cosmopolitan dimension is registered in none other than ren [仁] "benevolence", the foundational concept of the Confucian ethical system. For Confucius (551-479BC), only a cosmopolitan openness and generosity could render substantial assistance to others [博施与众而能济众人]. A man of benevolence is committed to establishing himself, and while doing so, he will also strive to help others to get established. And when seeking to distinguish himself, he will assist others to become illustrious as well [夫仁者, 已欲立而立人, 已欲达而达人] (Analects 6.30). Likewise, Mencius (372-289BC), Confucius' notable disciple, exhorts "to extend the respect for my own elders to the elders of others, and to extend love for my own children to the children of others." [老吾老以及人之老, 幼吾幼以及人之幼] (1.7) Going a step further than Confucius, Mencius expands this altruistic spirit from the others to tianxia [天下] or the whole world. As he puts it, "Cultivate the self when utterly deprived, and provide for the world when fully endowed." (13.9) The reason is that, he explains, "One could secure the peace of the Four Seas with cosmopolitan benevolence, but one could not even secure the peace of his wife if he declines to show such generosity." [推恩足以保四海, 不推恩无以保妻子] (1.7) The ancient phrase "Four Seas" refers to none other than tianxia. The Confucian value of benevolence indicates, therefore, a conspicuous altruistic cosmopolitanism.

If benevolence stresses the altruistic spirit to extend concerns for one's self and family members to the whole world, the concept of "diversity without uniformity" addresses directly attitudes towards cultural pluralism. Though first appearing in the Analects, this concept figures prominently in the Four Classics, a collection of classical writings on Confucian philosophy and ethics. ${ }^{26}$ For the Confucians, pluralism or diversity is a natural state of things. As Mencius puts it, "it is in the innate nature of things to differ from each other” [物之不齐, 物之情也], and “if

\footnotetext{
24 Ikenberry (2006:13).

25 Bell (2008: 25).

26 The Four Classics include The Analects, Mencius, Great Learning, and The Mean.
} 
one tries to make things uniform, confusion will arise.” [子比而同之, 是乱天下也] (Mencius 5.4) Likewise, Confucius asserts that differences need not lead to conflict, and contrary natures work in tandem. And this agreement between dissimilar natures is as natural as the alternation of the four seasons or the rotation of the sun and the moon. This is why "All forms of life grow together without harming each other, and the Dao of myriad things walk together without clashing with one another." [万物并育而不相害, 道并行而不相悖] (The Mean Chap30) Contrary natures not only work in tandem but also coexist harmoniously. In effect, diversity proves the very precondition for zhong [中] "equilibrium" and he [和] "harmony", two optimal states for things to grow and thrive. In The Mean, it is stated that "When things reach the supreme state of equilibrium and harmony, Heaven and Earth proceed in proper order, and all forms of life flourish.” [致中和, 天地位焉, 万物育 焉] (The Mean Chap1) The Confucian notion that harmony and equilibrium consist in the coexistence of contrary natures bespeaks, therefore, a pronounced cosmopolitan view of pluralism.

Altruistic cosmopolitanism proves a feature characterizing not only the Confucian but also the Taoist philosophy. The Taoist philosophers seem to display a vision much grander than that of the Confucians. Zhuangzi (370-287BC) famously declares that "Heaven and Earth are born with me, and all forms of life share the same Oneness with me.” [天地与我并生, 而万物与我齐一] (Chap2) For Zhuangzi, the equality of all forms of life resides in the inviolable integrity of their inborn natures. As he puts it, "to disrupt the Dao or the way of Heaven is to go against the natural disposition of things, an attempt that hinders the fulfillment of their innate natures.” [乱天之经，逆物之情，玄天弗成.] (Chap11) Like the Confucians, Zhuangzi links respect for diversity with the cultivation of ethical virtues as well. "Virtue means the harmonization of diversities and the Dao refers to the governing principles of things", he states, and "benevolence means to embrace all forms of life with virtue, and justice indicates to follow the principles of all things." [夫德, 和也; 道, 理也. 德无不容, 仁也; 道无不理, 义也] (Chap16) Resonating Mencius, Laozi (d.531), founder of the Taoist philosophy, also resorts to the self-world analogy to express cosmopolitan concerns. As he states: "Cherish the world just as one cherishes one's own body, such a man could be entrusted with the world; Love the world just as one loves one's own body, such a man could be commissioned with the world.” [故贵以身为天下, 若可寄天下; 爱以身为天下, 若可托天下] (laozi Chap13) Here the broad-minded cosmic vision, the insistence on the equality of all forms of life and respect for their innate natures, as well as the injunction to extend self-love to the world, all these Taoist notions betoken an all-embracing cosmopolitan spirit.

The term tianxia evokes naturally "tianxia guan" [天下观] and the "Tributary system" [进贡制], two ancient concepts reinvented by modern scholars to conceptualize China's vision of world order. As an institutional arrangement between imperial China and its Asian neighbors based on the core-periphery hierarchy, the tributary system necessarily sounds Sino-centric. Despite the recent revisionist readings that try to downplay or explain away this Sino-centrism, for China's neighbors who are unable or unwilling to view their tributary history in 
positive terms, the concept is still riddled with hegemonic valences. ${ }^{27}$ By contrast, the term tianxi or the world appears, at least literally, neutral. Zhao Tingyang is the first to call attention to the relevance of tianxia to a Chinese IR, an initiative that triggers an intense scholarly debate. ${ }^{28}$ As William A. Callahan puts it, "the Tianxia System became a best-seller in China because it caught a wave of interest in Chinese-style solutions to world problems, and especially an interest in how the traditional concept of Tianxia combines the seemingly contradictory discourses of nationalism and cosmopolitanism". ${ }^{29}$ But Zhao's understanding of tianxia as a "world institution" and his failure to account for the Sino-centric implications of this concept tend to discount its theoretical value. ${ }^{30}$ Callahan argues that "the power of Tianxia comes less from the sophistication of its theoretical argument than from its strategic placement in China's discursive networks of power". And as such, Callahan says, "Tianxia presents a new hegemony where imperial China's hierarchical governance is updated for the twenty-first century". 31

In fact, a notable flaw in the modern views of the tianxia guan and the tributary system is their neglect of the primary meaning of tianxia as a term for the universe or cosmos. The cosmological dimension of tianxia actually constitutes the metaphysical underpinning of the cosmopolitan insights in Chinese philosophical discourse. The Chinese name for the cosmos is yuzhou [宇宙]. As Zhuangzi states: "That which is real but cannot be located is called $y u$ [宇] or the four directions; that which extends without end and beginning is called zhou [宙] or temporal time.” [有 实而无乎处者, 宇也; 有长而无本剽者, 宙也.] (Chap23) For the Taoist philosopher, people with a cosmic vision could "ride upon the clouds, mount the sun and the moon, and roam beyond the Four Seas.” [乘云气, 骑日月, 而游乎四海之外] (Chap2) Likewise, Xunzi (314-217BC), the highly renowned Confucian philosopher, holds that people with a cosmic horizon could

know the Four Seas while sitting in the room, discourse on the distant past, comprehend all forms of things and their innate natures, discern the laws governing the ups and downs of all times, and weave the warp and woof of Heaven and Earth, instituting the grand ethical norms by modeling after and utilizing the patterns of all things. In this way, the whole universe would be put in good order. [坐于室而见四海, 处于今而论久远, 疏观万物而知其情, 参稽治乱而通其度, 经纬天地而材官万物, 制割大理, 而宇宙理矣] (xunzi Chap21)

The quoted passages do sound idealistic and even utopian, but metaphysically speaking they evince a grand cosmic perspective to view the self through the larger lens of the universe. This cosmic lens that symbolizes China's ancient conception of

\footnotetext{
${ }^{27}$ For classic readings of the Tributary system see Fairbank (1968); for revisionist readings see Zhou Fangyin (2011), Song (2012) and Zhang and Buzan (2012).

${ }^{28}$ Zhao Tingyang (2005).

29 Callahan (2008: 750).

30 Zhao Tingyang (2005: 32, 30).

31 Callahan (2008: 750).
} 
its relationship with and position in the universe proves the primal wellspring of Chinese cosmopolitan thinking.

\section{The Bene-Ideal and China's Foreign Policy}

The bene-ideal fostered by the cosmopolitan spirit in the Taoist and Confucian philosophy could serve as a pertinent model to conceptualize Chinese foreign policy. The "Five Principles of Peaceful Coexistence" has been the overarching foreign policy framework for the new Republic. But this framework proves insufficient to address China's increasingly intense involvement in global governance, especially its leadership role in such multilateral forums as the WTO and G-20. To fully articulate China's proactive role in shaping global agendas, the "Five Principle" paradigm should integrate the bene-ideal as a guiding principle, for two reasons. First, the bene-ideal model can account for the continuity and evolution of Chinese foreign policy in the past three decades. Second, the prominent altruism expressed by the bene-ideal aptly captures the cosmopolitan orientation in the foreign policy discourse of the $\mathrm{Xi}$ administration.

The bene-ideal that epitomizes the ancient insight on relationships with the broader world is actually the core value upon which China's foreign policy has been predicated. To facilitate the opening and reform policy, President Deng Xiaoping proposed the concept of taoguang yanghui, yousuo zuowei" [韬光养晦, 有所作为] as the blueprint for China's foreign policy. Most scholars translate taoguang yanghui as "keeping a low profile", a rendering that exaggerates its strategic at the expense of its cultural connotations. In effect, Deng's policy derives directly from the cosmopolitan thinking in the Taoist and Confucian philosophy, especially the bene-wish outlined in Mencius' injunction to "cultivate the self when utterly deprived, and provide for the world when fully endowed". Whereas taoguang yanghui means to cultivate and strengthen the self when less endowed, yousuo zuowei indicates to reach out and benefit others when one becomes empowered. The rationale is that, only when fully endowed, one could reach out to make a difference in others' life.

The bene-ideal was given different expressions and levels of emphasis by the four administrations since 1978, but it receives a most pronounced articulation in the foreign policy discourse of the $\mathrm{Xi}$ administration. The reason is apparent. Three decades after the introduction of the reform and opening policy, China has reached the state of 达-it has obtained the material and moral capabilities to better the world. This is why President Xi Jinping repeatedly states China's wish to share its fruits of development in various international forums. Xi's Foreign Minister Wang Yi explicitly declares that "if China's development cannot be shared by the world, its development will surely be unsustainable", and China's deepening reform will continue to "focus on win-win cooperation and common prosperity". 32

So the time is ripe for China to conceive a world order from the cosmopolitan perspective. President Xi's speech at the UNESCO Headquarters in March 2014

\footnotetext{
32 Wang Yi (2013:14, 15).
} 
exemplifies this paradigmatic shift in Chinese foreign policy thinking. In this speech, Xi maps out a cosmopolitan vision of world order that emphasizes the equal worth and agency of all civilizations. ${ }^{33}$ To illustrate the indispensable role of all civilizations to maintaining a "harmonious world", $\mathrm{Xi}$ cites a statement of Yan Ying, Prime Minister of the State of Qi, as recorded in the ancient text zuozhuan [左 传] The Chronicle of Zuo. According to Yan, "Harmony can be illustrated by soupmaking. To bring out the special flavor of fish or meat, one needs to add such ingredients as water, fire, vinegar, meat sauce, salt, and plum". In like manner, Yan observes, "a harmonious melody can only be produced through a proper combination of the texture, length, pace, mood, tone, pitch, and style of a piece of music". ${ }^{34}$ Here Yan uses the two metaphors to elucidate the necessity of making harmony out of diversity. Whereas the soup analogy emphasizes the necessary presence of diverse elements in the making of a rich flavor, the music image underscores the importance of combining a variety of different musical skills to produce a tuneful melody. Yan's metaphors suggest that, Xi interprets, "it is impossible to imagine a world consisting only of one lifestyle, one language, one kind of music, and one style of costume". As a harmonious symphony is woven out of the voices of all civilizations, $\mathrm{Xi}$ concludes, it is but natural "for peoples of different cultures, ethnic groups, skin colors, religious beliefs, and social systems to be bonded together in a common community of shared destiny." [命运共同体]

The concept of a "harmonious world" is an initiative of President Hu Jintao, but it is President Xi Jinping who infuses into this concept with a prominent cosmopolitan spirit. This is shown in not only Xi's evoking of the soup and music metaphors but also his quotation of Chinese proverbs rich in cosmopolitan connotations. Six such popular sayings stand out in Xi's UNESCO speech. Three of them, that is, "Diversity without uniformity", "It is in the innate nature of things to differ from each other", as well as "Not a single but a rich variety of flowers makes spring", signal a cosmopolitan recognition of the natural existence and coexistence of global diversities. The fourth, "The Ocean is vast as it opens up to all rivers", speaks to the same cosmopolitan amplitude to accommodate all manners of pluralism. The last two, "Radish or cabbage, each to his own delight" and "Cutting one's feet to fit one's shoes", address at once the necessity for states to choose their own way of development and the futility to impose one's own will upon others. The President's quotation of common proverbs and ancient sayings notable for their cosmopolitan associations in an international forum indicates an undeniable cosmopolitan orientation in Chinese foreign policy. That the remarks in Xi's UNESCO speech reoccur and resonate in many of his other statements does point to a conceptual shift in China's foreign policy discourse.

\footnotetext{
33 Xi (2014). Xi Jinping, Speech at the UNESCO headquarters on 28 March 2014. http://news.xinhuanet. com/world/2014-03/28/c_119982831.htm. Accessed 6 Aug 2015. All quotes about this speech are from this website.

34 For the original text see Chronicle of Zuo, in Shi Zonglian ed., 640. (2013)
} 


\section{The Chinese Dream and Civilizational Identity}

The bene-ideal reflects not only China's foreign policy but also its national identity, because a distinctive and well-defined identity is the anchor point for a nation to position itself vis $a$ vis both itself and the rest of the world. The new initiative of the Chinese dream provides an ideal platform for national identity building. Ever since Deng Xiaoping pronounced the reform and opening policy, China has been unsure of its national identity, an uncertainty that appears the more noticeable with its growing status in global affairs. As a native scholar puts it, "currently, there is no consensus on China's identity, whether at home or abroad", though "in recent years, China has strategically been identifying itself in a multidimensional and multilayer way", calling itself a "major power", "developing country", "emerging economy", or "major developing country". 35 The Dream project that attempts to revitalize the nation's civilizational legacy could incorporate all the above concepts within the discourse of national identity building. Both Zhang Weiwei and Martin Jacques propose the idea of "civilizational state" to describe the centrality of Chinese civilization to its identity. ${ }^{36}$ Jacques rightly states that "Chinese identity is overwhelmingly a product of its civilizational history", since for the Chinese "it is not only history that lives but civilization itself: the notion of Chinese civilization as a living and dynamic organism rather than a static and inanimate object provides the primary identity and context by which the Chinese think of their country and define themselves". ${ }^{37}$ Given its core mission to reclaim China's civilizational lineage, the Dream project should focus on formulating a civilizational identity based on values and ideals engrained in Chinese culture.

But what is, after all, the national image or civilizational identity China seeks to rejuvenate? The European vision of China in the Renaissance provides some revealing clues. In the fifteenth and sixteenth centuries, the magnetic pull of the Chinese civilization has famously set in motion the "race for the Far East". Allured by the glittering image of China depicted by the thirteenth-century Italian traveller Marco Polo, thousands of people from early modern Spain, Portugal, England, and the Netherlands embarked on exploratory adventures that ultimately led to the discovery of the Indian Ocean and the New World. Maritime explorations broke free the four terminuses delimited by Ptolemy and set the stage, for the first time in human history, for global interactions between the vast arrays of civilizations unleashed from the terra incognita. China's advanced science proved instrumental to those unprecedented waves of maritime movements. In his The New Organon (1620), Francis Bacon, the English Lord Chancellor and founder of the experimental science, declares that the three inventions of China-printing, gunpowder, and the magnet- "have changed the whole face and state of things throughout the world; the first in literature; the second in warfare; the third in navigation". ${ }^{38}$ In fact, what attracted the West to the East is not only Chinese science but also its history and

\footnotetext{
35 Yang (2014: 4-5). For China's various identities see Chan (2014:265).

36 Zhang Weiwei (2012), Jacques (2009: 244).

37 Jacques (2009: 244, 252).

38 Bacon (1620, 1960: 118).
} 
ethical and political systems. In his "On Experience", the French essayist Michel de Montaigne commends China's excellent polity and sciences as exemplars for the West. For Montaigne, it is China's long and uninterrupted history that made him realize how "abundant and diverse" the world is. ${ }^{39}$ Joseph Scaliger, founder of the chronological science, holds that China's highly efficient political governance and peaceful civic order put shame to the French who were constantly embroiled in civil strife. John Webb, the English architect who composed the first systematic treatise on the Chinese language, argues that Chinese monarchs who are noted for their high political and moral principles are the very epitome of Plato's philosopher kings. ${ }^{40} \mathrm{~A}$ civilized state with a highly advanced ethical and political system, a long and illuminating history, as well as a rich and edifying cultural heritage- this should be the national image the Dream project seeks to bring to life.

In addition to revitalizing its civilizational identity, the Dream initiative should also serve as a cultural framework for the world to view China. Jan Melissen and Ingrid d'Hooghe well observe that the Chinese dream is not merely a national program but also "an international project that may add to China's efforts to explain itself and improve oversees opinions". Most importantly, its architect "hopes the Dream may become relevant to foreigners' thinking about China, its identity, and its future course". ${ }^{41}$ As is shown in President Xi's repeated emphasis on mutually enabling civilizational interactions and his proposal to establish a "common community of shared destiny", the Dream framework does aspire to express the needs and desires common to all. Xi pointedly articulated the global resonance of the Chinese dream in his Annenberg meeting with the US President Barack Obama. As he puts it, "The Chinese dream is committed to prospering the economy, invigorating the nation, and making the people happy. Globally speaking, it intends to enhance international cooperation, development, peace building, and mutual benefits. The dream of the Chinese is compatible with the dreams of peoples in all the other countries". ${ }^{42}$ This cosmopolitan aspect of the Dream project accords well with the bene-ideal that insists on the equal worth and rights of all civilizations in the international system.

To make the Chinese dream an expression of common aspirations, it is imperative to universalize the core values and ideals constituting its civilizational identity, making them relatable to the international community. ${ }^{43}$ The past few years have witnessed a rising trend to search for universal values in the classical writings among the Chinese scholarly and policy-making communities. The underlying assumption is that, if those antique values could be proved universal, then China will have its soft power arsenal, an intellectual asset that can boost its discourse right in global public debate. No one would doubt that a civilization that has withstood several thousand years' test should harbor a rich repository of lasting

\footnotetext{
39 Montaigne (1590, 2003:1215).

40 Webb (1669: 92-93).

41 Melissen and d'Hooghe (2014: 18).

42 Xi (2013). Xi Jinping, Chinese dream is compatible with American dream. http://world.huanqiu.com/ regions/2013-06/4014859.html. Accessed 6 Aug 2014.

43 On China's soft power see Kurlantzick (2007) and Li Mingjiang (2008).
} 
values, if time is the veritable touchstone of truth. But as Melissen and d'Hooghe point out, "a lot of effort has not produced the desired results", since global public opinion seems not to resonate. ${ }^{44}$

A major cause of this failure is the improper identification and conceptualization of the universal values engrained in Chinese culture. Those ideals constantly promoted by the Chinese government such as "cultural uniqueness" and "special characteristics" are not values that foreign people can relate to. For instance, Buzan interprets "Chinese characteristics" as "an inward-looking type of national exceptionalism" and "a culturally unique way of doing things that is not necessarily relevant to those outside Chinese culture". 45 The 18th National Congress proposed a "core socialist values" system comprising 24 words: prosperity, democracy, civility, harmony, freedom, equality, justice, rule of law, patriotism, dedication, integrity, and friendship. But lacking a compelling narrative, relevant context, and substantial content, these laudable values remain abstract categories that bear little on lived experiences. This is why most Western media have kept silence despite Beijing's high-profile promotion of these values. As Yu Xintian suggests, Beijing should focus on both the unique and common features of the Chinese values, since only ideals that address shared human experiences and conditions can evoke universal empathy. ${ }^{46}$ The Dream project should be a pertinent platform to mobilize and integrate the Chinese universal values into a systematic and compelling narrative that expresses the needs and desires common to all.

\section{The Bene-Ideal and Civilizational Cosmopolis}

As two key IR variables, culture and civilization are two distinct though interconnected concepts. Culture concerns beliefs, values, and symbols, and is thereby an ideational category oppositional to the social, political, or economic. By contrast, as "the highest cultural groupings of people and the broadest level of cultural identity people have short of that which distinguishes humans from other species", 47 civilization is comparable to the "continental, regional, societal, and other definitions of the global-human condition". 48 The English school regards culture as a key driver of the international system, because "the logic of anarchy, operating in the international system, has brought states into international society; once in, the logic of culture has determined their degree of integration into international society". ${ }^{49}$ But as Wang and Buzan point out, "according to this logic, if culture were diverse, then international society could be only weakly integrated". 50 The incapacity of the category of culture to fully capture global

\footnotetext{
${ }^{44}$ Melissen and d'Hooghe (2014: 23).

45 Buzan (2010a: 21).

46 Yu (2013: 65-66).

47 Huntington (1993: 22).

48 Robertson (1992: 70).

49 Riemer and Stivachtis (2002: 27).

50 Wang and Buzan (2014: 34).
} 
diversities has shifted scholarly attention to the broader concept of civilization. Unlike cultural disparity that entails ethnic, racial, or religious conflict, civilizational pluralism that signifies the crystallization of human wisdom and progress speaks of a "global-human condition" beyond any dispute.

But the concept of civilization, though neutral in itself, could be manipulated and invested with an ideational valence as well. What dominated the international scene before the two world wars is the Western "Standard of civilization" that arose with the imperial agenda in the nineteenth century. But this imperial Standard was discredited as an international legal norm due to its inability to contain the two wars. Since the end of the cold war the concept of civilization has acquired a new currency. ${ }^{51}$ Zhang Yongjin holds that the standard of civilization "has had and continues to have a pervasive influence in structuring institutional and normative constructs of international society". 52 For Gerrit Gong, "some standard of civilization will remain a feature of any international society wherein cultural diversity and pluralism exists coetaneously with hierarchy and anarchy", serving as "an important thread in the social, legal, and institutional fabric of contemporary international society" ${ }^{53}$ Despite its new relevance, however, civilization remains a contested norm, though on a different plane. In the post-cold war era, the Western "Standard of civilization" has remerged under the garb of neoliberalism. But such neoliberal principles as human rights, democracy, or the rule of law, Buzan says, "come wrapped in more anodyne and bureaucratic terms such as 'conditionality', 'good governance' and 'development", 54 As such these new civilizational norms tend to impose a different set of constraints, especially for non-democratic states.

The bene-ideal draws on the insights of Zhang and Gong on the relevance of the civilizational standard to contemporary international society. But unlike the Western Standard that seeks to impose its own rules and norms upon other states, the bene-ideal emphasizes the equal rights and worth of all civilizations, and thereby gestures toward a new civilizational standard. The civilization thesis entailed in the bene-ideal also differs from Huntington's hypothesis of the "clash of civilizations". For Huntington, "the cultural fault lines separating civilizations" would be their "battle lines". ${ }^{55}$ By contrast, in his UNESCO speech, the Chinese President declares that cultural disparity makes communications and mutual learning among different civilizations especially relevant and valuable, because such exchanges "could help open our hearts, broaden our horizon, and foster greater consensus". As greater convergence in the moral and intellectual sphere represents "a higher standard of humanity", Xi remarks, civilizational interactions could boost human progress in general.

Given its emphasis on the equality and worth of all civilizations, the world order envisioned by the bene-ideal is a civilizational cosmopolis or community committed to universally shared spiritual and ethical values. Barry Gills distinguishes between

\footnotetext{
51 Gong (1984), Katzenstein, ed. (2009), Buzan (2014), Zhang (2014) and Bowden (2014).

52 Zhang Yongjin (2014: 677).

53 Gong (1984: 248, 93).

54 Buzan (2014: 577).

55 Huntington (1993: 25, 46).
} 
empire and cosmopolis - two archetypical concepts that address relations beyond the nation states. While empire means "the naked pursuit of power and wealth", cosmopolis signifies "our spiritual side and our quest for harmony, moral order, and community". ${ }^{56}$ In conceiving a community of civilizations bonded together by a shared destiny, the bene-ideal points to none other than a civilizational cosmopolis committed to the "quest for harmony, moral order, and community". A civilizational cosmopolis, however, differs from a "universal state" based on Chinese values. Bell rightly claims that it is futile to make a case for "cosmopolitan political institutions inspired by Confucian principles", since "it is difficult to imagine that one global ruler or political institution will ever be able to secure political legitimacy among all the different cultures and worldviews". 57 Rather than a political organization, civilizational cosmopolis signifies "our spiritual side" and the cosmopolitan spirit to achieve win-win outcomes by tapping on the wisdom and accomplishments of all civilizations. The legitimacy and credibility of such a community should derive from its presumably universal membership.

\section{Conclusion}

The bene-ideal that reflects at once China's vision of world order, foreign policy thinking, and national identity provides not only a core concept for Chinese IR but also a pertinent lens for foreign observers to view China. Meanwhile, the bene-ideal framework also brings to light how emerging powers like China could accommodate and reform the existing system, and how politically and culturally diverse civilizations can be economically integrated and peacefully coexist. Viewed in the light of the bene-ideal model, economic globalization and civilizational pluralism could sit comfortably together in a world order woven out of civilizational interactions.

Acknowledgments I'm indebted to Professor Yu Xintian and Professor Cai Penghong in Shanghai Institute of International Studies (SIIS) for their insightful inputs. I'm also grateful to Professor David Porter in the English department at the University of Michigan for sharing his insights with me.

\section{References}

Bacon, Francis. 1620, Reprt. 1960. The new organon, and related writings, ed. Fulton H. Anderson. Indianapolis: Bobbs-Merrill.

Barabantseva, Elena. 2009. Change vs. Order: Shijie Meets Tianxia in China's Interactions with the World. Alternatives: Global, Local, Political 34(2): 129-155.

Bell, Daniel A. 2008. China's new Confucianism: Politics and everyday life in a changing society. Princeton: Princeton University Press.

Bowden, Brett. 2014. To rethink standards of civilisation, start with the end. Millennium 42(3): 614-631. Bull, Hedley. 1977, Reprt. 2002. The anarchical society: A study of order in world politics, 3rd edn. New York: Columbia University Press.

\footnotetext{
${ }^{56}$ Gills (2005: 5, 6.9).

57 Bell (2008: 25).
} 
Buzan, Barry. 2010a. China in international society: Is 'Peaceful Rise' possible? Chinese Journal of International Politics 3(1): 5-36.

Buzan, Barry. 2010b. Culture and international society. International Affairs 86(1): 1-25.

Buzan, Barry. 2014. 'The Standard of Civilization' as an English school concept. Journal of International Studies 42(3): 576-594.

Callahan, William A. 2008. Chinese visions of world order: Post-hegemonic or a new hegemony? International Studies Review 10: 749-761.

Chan, Gerald. 2014. Capturing China's international identity: Social evolution and its missing links. Chinese Journal of International Politics 7(2): 261-281.

Cunningham-Cross, Linsay, Callahan, William A. 2011. Ancient Chinese Power, Modern Chinese Thought. Chinese Journal of International Politics 4(4): 349-374.

Fairbank, John King. (ed.) 1968. The Chinese World Order: Traditional China's Foreign Relations. Cambridge: Harvard University Press.

Feng, Huiyun. 2008. Is China a revisionist power? Chinese Journal of International Politics 2(3): 313334.

Gills, Barry K. 2005. 'Empire' versus 'Cosmopolis': The clash of globalization. Globalizations 2(1): 513.

Gong, Gerritt W. 1984. The standard of 'civilization' in international society. Oxford: Clarendon Press. Held, David. 2010. Cosmopolitanism: Ideals and realities. London: Polity.

Hollinger, David A. 1995. Postethnic America: Beyond multiculturalism. New York: Harper Collins.

Huntington, Samuel. 1993. The clash of civilization? Foreign Affairs 72(3): 22-49.

Ikenberry, G.John. 2006. Liberal order \& imperial ambition. London: Polity.

Ikenberry, G.John. 2011. Liberal Leviathan: The origins, crisis, and transformation of the American world order. Princeton: Princeton University Press.

Jackson, Peter. 2008. Pierre Bourdieu, the 'Cultural Turn'" and the practice of international history. Review of International Studies 34: 155-181.

Jacques, Martin. 2009. When China rules the world: The end of the western world and the birth of a new global order. New York: Penguin Books.

Johnston, Alastair Iain. 2003. Is China a Status Quo power? International Security 27(4): 5-56.

Katzenstein, Peter (ed.) 2009. Civilizations in world politics: Plural and pluralistic perspectives. New York: Routledge.

Kurlantzick, Joshua. 2007. Charm offensive: How China's soft power is transforming the world. New Haven: Yale University Press.

Laozi, 2013. Annotated by Rao Shangkuan. Beijing: Zhonghua shuju.

Legro, Jeffrey W. 2007. What China will want: The future intentions of a rising power. Perspectives on Politics 5(3): 515-534.

Li, Mingjiang. 2008. China debates soft power. Chinese Journal of International Politics 2(2): 288-308.

Melissen, Jan, and Ingrid d'Hooghe. 2014. The Chinese dream and successful communication with the world. SIIS, Global Review (Spring), 17-27.

Mencius, 2014. Annotated by Yang Bojun. Beijing, Zhonghua Shuju.

Montaigne, Michel de. 1590; Reprt. 2003. On experience. In The complete essays. (trans.) M.A. Screech. London: Penguin Books.

Pan, Zhongqi. 2008. China's changing image of and engagement in world order. In Harmonious world and China's new foreign policy, ed. Guo Sujian, and Jean-Marc F. Blanchard, 39-63. New York: Rowman.

Porter, David. 2011. What is universal about universal human rights? CICS International Connections 3 (2): 6-10.

Qin, Yaqing. 2011. Development of international relations theory in China: Progress through debates. International Relations of the Asia-Pacific 11: 231-257.

Qin, Yaqing. 2009. Guanxi benwei yu guocheng jiangou: jiang Zhongguo linian zhiru guoji guanxi lilun (relationality and procedural construction: Bringing Chinese ideas into international relations theory'). Zhongguo shehui kexue (Social Science in China), 69-86.

Riemer, Andrea K., and Yannis A. Stivachtis (eds.). 2002. Understanding EU's mediterranean enlargement: The English school and the expansion of regional international societies. Frankfurt: Peter Lang.

Robertson, Roland. 1992. Globalization: Social theory and global culture. London: Sage.

Ruggie, John G. 1982. International regimes, transactions, and change: Embedded liberalism in the postwar economic order. International Organization International Regimes 36(2): 379-415. 
Song, Nianshen. 2012. 'Tributary' from a multilateral and multilayered perspective. Chinese Journal of International Politics 5(2): 155-182.

The mean and great learning, 2006. Annotated by Wang Guoxuan. Beijing: Zhonghua Shuju.

The Analects, 2012. Annotated by Yang Bojun. Beijing: Zhonghua Shuju.

Van Elteren, Mel. 2006. Imperial gestures in portrayals of U.S. culture as a 'Universal Culture'. American Studies 51(2): 207-238.

Wang, Yi. 2013. Exploring the path of major-country diplomacy with Chinese characteristics. http:// www.en84.com/nonfiction/remarks/201306/00012914.html. Accessed 26 March 2016.

Wang, Jiangli, and Barry Buzan. 2014. The English and Chinese schools of international relations: Comparisons and lessons. Chinese Journal of International Politics 7(1): 1-46.

Webb, John. 1669. An historical essay endeavoring a probability that the language of the empire of China is the primitive language. London: Brook.

Went, Robert. 2004. Economic globalization plus cosmopolitanism. Review of International Political Economy 11(2): 337-355.

Xi, Jinping. 2013. Chinese dream is compatible with American dream. http://world.huanqiu.com/regions/ 2013-06/4014859.html. Accessed 6 Aug 2014.

Xi, Jinping. 2014. Xi's speech at the UNESCO headquarters on March 28, 2014. http://news.xinhuanet. com/world/2014-03/28/c_119982831.htm. Accessed 6 Aug 2015.

Xunzi, 2013. Annotated by An Xiaolan. Beijing: Zhonghua shuju.

Yan, Xuetong. (2011) Ancient Chinese Thought, Modern Chinese Power, (ed.) Dainile A. Bell and Sun Zhe; (trans.) Edmund Ryden. Princeton: Princeton University Press.

Yang, Jiemian. 2014. Strategic readjustment of China's diplomatic strategy at a new starting point. SIIS, Global Review (Spring), 1-16.

Yu, Xintian. 2013. The significance of Chinese values in the world. China International Studies, 4 :46-68.

Zhang, Xiaoming. 2010. Correspondence: Debating China's peaceful rise. Chinese Journal of International Politics 3(4): 447-460.

Zhang, Weiwei. 2012. The China wave: Rise of a civilization state. Hackensack, NJ: World Scientific Publishing.

Zhang, Yongjin. 2014. The standard of 'Civilisation' redux: Towards the expansion of international society 3.0? Millennium 42(3): 674-696.

Zhang, Yongjin, and Barry Buzan. 2012. The tributary system as international society in theory and practice. Chinese Journal of International Politics 5(1): 3-36.

Zhao, Tingyang. 2005. Tianxia tixi: Shijie zhidu zhexue daolun (the Tianxia system; a philosophy for the world institution). Nanjing: Jiangsu Jiaoyu Publisher.

Zheng, Bijian (ed.) 2003. The road of China's peaceful rise [Zhongguo heping jueqi de daolu]. Beijing: The CCP Central Party School Press.

Zhou, Fangyin. 2011. Equilibrium Analysis of the Tributary System. Chinese Journal of International Politics 4(2): 147-178.

Zhuangzi, 2015. Annotated by Fang Yong. Beijing: Zhonghua shuju.

Zuozhuan, 2013. In The Four Books and Five Classics, ed. Shi Zonglian, 640-641. Shanghai: Shanghai cishu chubanshe.

Mingjun Lu received her doctorate from the English Department at the University of Toronto, her MA in Global Affairs (MGA) at the University of Toronto's Munk Center, and her MA in literature and translation at Nanjing University, China. Lu has published several journal articles and translated books. She is the author of The Chinese Impact upon English Renaissance Literature: A Globalization and Liberal Cosmopolitan Approach to Donne and Milton (Ashgate, 2015). 